GRASAS Y ACEITES $72(1)$

January-March 2021, e397

ISSN-L: 0017-3495

https://doi.org/10.3989/gya.1147192

\title{
Shelf-life of Moroccan prickly pear (Opuntia ficus-indica) and argan (Argania spinosa) oils: a comparative study
}

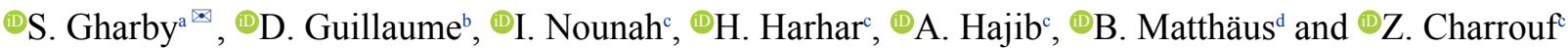 \\ ${ }^{a}$ Laboratory Biotechnology, Materials and Environment (LBME), Faculty Polydisciplinary of Taroudant, University Ibn Zohr, Morocco \\ ${ }^{b}$ CNRS-UMR7312, School of Medicine and Pharmacy, 51 rue Cognacq Jay, 51100 Reims, France \\ ${ }^{\mathrm{c}}$ Laboratory of Plant Chemistry and Organic and Bioorganic Synthesis, Faculty of Sciences, Mohammed V University, Rabat, Morocco \\ ${ }^{\mathrm{d}}$ Max Rubner-Institut, Federal Research Institute for Nutrition and Food, Department for Safety and Quality of Cereals, Working Group \\ for Lipid Research, Schützenberg 12, 32756 Detmold, Germany \\ ${ }^{\bowtie}$ Corresponding author: s.gharby@uiz.ac.ma
}

Submitted: November 28, 2019; Accepted: February 25, 2020; Published online: February 24, 2021

SUMMARY: Cactus seed oil is gaining considerable popularity in the cosmetic industry. To estimate cactus seed oil' industrial as well as domestic ease of use, we investigated the oxidative stability of Moroccan cactus seed oil under accelerated aging conditions. In addition, we compared cactus seed oil stability to that of argan oil, a popular and well-established cosmetic oil, under the same conditions. Cactus seed oil is much more sensitive to oxidation than argan oil. Its shelf-life can be estimated to be no longer than 6 months at room temperature. Such instability means that the preparation process for cactus oil must be carried out with great care and cactus seed oil needs to be protected once extracted.

KEYWORDS: Cosmetics; Oil preservation; Oxidative stability

RESUMEN: Vida útil de los aceites de cactus marroquí (Opuntia ficus-indica) y de argán (Argania spinosa). Estudio comparativo. El aceite de semillas de cactus está ganando considerable popularidad en la industria cosmética. Para estimar la facilidad de uso industrial y doméstico del aceite de semilla de cactus, investigamos la estabilidad oxidativa del aceite de semilla de cactus marroquí en condiciones de envejecimiento acelerado. Además, comparamos, bajo las mismas condiciones, la estabilidad del aceite de semilla de cactus con la del aceite de argán, otro aceite cosmético popular y bien establecido. El aceite de semilla de cactus es mucho más sensible a la oxidación que el aceite de argán. Su vida útil se puede estimar en no más de 6 meses a temperatura ambiente. Tal inestabilidad significa que los procesos preparativos del aceite de cactus deben manejarse con mucho cuidado y el aceite de semilla de cactus debe protegerse una vez extraído.

PALABRAS CLAVE: Cosmética; Estabilidad oxidativa; Preservación de aceite

Citation/Cómo citar este artículo: Gharby S, Guillaume D, Nounah I, Harhar H, Hajib A, Matthäus B, Charrouf Z. 2021. Shelf life of Moroccan prickly pear (Opuntia ficus-indica) and argan (Argania spinosa) oils: a comparative study. Grasas Aceites 72 (1), e397. https:// doi.org/10.3989/gya.1147192

Copyright: (C2021 CSIC. This is an open-access article distributed under the terms of the Creative Commons Attribution 4.0 International (CC BY 4.0) License. 


\section{INTRODUCTION}

The world of cosmetics is characterized by a constant search for new compounds which are able of satisfy customer demands and high expectations. While the presentation of commercial-only arguments has long been considered satisfactory by the customers, a trend has recently emerged that customers are more inclined to ask for scientific evidences to back up the new cosmetics. A few years ago, argan oil was lauched on the cosmetic market with extensive advertising but also with scientific studies validating its claimed or empirically observed properties (Charrouf and Guillaume, 2008; Guillaume and Charrouf, 2011; Charrouf and Guillaume, 2014). With such an approach, the commercial success of argan oil has been global and its acceptance by the public almost immediate.

The argan tree is only endemically grown in Morocco. Therefore, argan oil is an organic compound originating only from Morocco. It is prepared by simply cold-pressing argan kernels collected following a rigorous process (Charrouf et al., 2002) that has been protected by a geographical indication since 2009 (Charrouf and Guillaume, 2018). The simplicity of the preparation of argan oil ascertains its original chemical purity, a factor particularly appreciated by consumers. Argan oil has high contents in unsaturated fatty acids, as well as tocopherols and phytosterols, which have been repeatedly shown to be responsible for most of its dermocosmetic properties (Guillaume and Charrouf, 2011; Guillaume and Charrouf, 2013; Zaanoun et al., 2014).

The worldwide economic success of cosmetic argan oil has encouraged the search for other oil seeds which present sufficiently similar chemical profile. Tooga (Balanites aegyptiaca) and prickly pear (Opuntia ficus-indica L.) oil seeds (Guillaume et al., 2015) are currently receiving a lot of attention. Among these two seed oils, the marketing of the latter is much more advanced and, actually, cactus oil has only recently entered the cosmetic market (Ciriminna et al., 2017). It could also be a source of edible oil (Salvo et al., 2002).

Similar to those of argan oil, the triglycerides of cactus oil are mostly unsaturated fatty acids. Cactus oil also contains large amounts of sterols and tocopherols (Ciriminna et al., 2017), two classes of phytocompounds considered to be important and valuable by the cosmetics industry. In both argan and cactus oils, the total content in oleic (monounsaturated) and linoleic (diunsaturated) acids, is around $80 \%$ (Labuschagne and Hugo, 2010). However, linoleic acid is the overwhelmingly predominant fatty acid in cactus oil, with a content of around $55 \%$ vs only $15-20 \%$ for oleic acid (Labuschagne and Hugo, 2010; Ramadan and Mörsel, 2003); whereas in argan oil the oleic acid content slightly surpasses that of linoleic acid (48 vs $32 \%$, respectively) (Charrouf and Guillaume, 1999; Zaanoun et al., 2014). Despite this difference in fatty acid concentrations, cactus seed oil's content in unsaturated fatty acids supports the idea that this seed oil is perfectly suitable for large-scale use as a major ingredient in cosmetology (Sawaya and Khan, 1982) and could follow the path of cosmetic argan oil.

Cactus seed oil is prepared by press-extraction of the seeds. However, cactus seeds are difficult to break and even though a yield in cactus oil of $13.6 \%$ has been reported from Moroccan cactus seeds (El Finti et al., 2013), most reported yields for cactus seed oil generally lie between 7.3 and $9.3 \%$, possibly depending on the geographical origin of the seeds (Ciriminna et al., 2017), or on the maturation period (Coskuner and Tekin, 2003). For comparison purposes, argan kernels contain up to $50 \%$ of oil (Harhar et al., 2010). Consequently, cactus seeds that have been simply considered as waste for years, now contain the "most expensive oil in the world" with market prices possibly reaching $500 € / \mathrm{L}$ vs $120 € / \mathrm{L}$ for argan oil, which previously held this title.

The prickly pear is a ubiquitous Mediterraneantype cactus which is well-adapted to extreme arid conditions. It is a wild-growing or cultivated plant in Morocco whose cladodes and fruit have received some attention mainly for a use as livestcock feed or human food (Feugang et al., 2006; De Waal et al., 2015). Unlike argan oil, whose traditional uses are well-documented (Charrouf and Guillaume, 1999), cactus seed oil's promising cosmetic and pharmacological properties are almost exclusively a direct consequence of its chemical composition (Sawaya and Khan, 1982) and to our knowledge, there are no reports of a traditional extraction of cactus seed oil. Nevertheless, cactus seed oil could enjoy great commercial success. However, the use of cactus oil by the cosmetic industry could be limited or at least difficult because of its poor preservation properties and chemical 
modifications in its composition occurring during aging. Indeed, cactus seed oil induction time calculated by the Rancimat accelerated method, has been found to be of only $7 \pm 1 \mathrm{~h}$ at $110{ }^{\circ} \mathrm{C}$ (Zine et al., 2013). Again, for comparison purposes, in the same experimental conditions, cosmetic argan oil induction time has been calculated to be twice as long (Gharby et al., 2012a). Consequently, with regard to its elevated market price, we decided to investigate further the oxidative stability of the cactus seed oil from Morocco to possibly estimate its shelf-life. We performed our study using storage at $60{ }^{\circ} \mathrm{C}$ to amplify and accelerate oxidative processes as we previously did for edible argan oil (Gharby et al., 2012a; Matthäus et al., 2010). Our results on Moroccan cactus seed oil are evaluated in the light of those obtained with a similar set of analyses carried out on cosmetic argan oil samples stored under the same conditions.

\section{MATERIALS AND METHODS}

\subsection{Materials and experimental design}

Argan fruit was collected in Tiout (Taroudant County) in August, 2014 and prepared following the methodology used by the local women's cooperative. The fruit was air-dried for 3 weeks then mechanically de-hulled (SMIR Technotour, Agadir, Morocco). Manually opened argan nuts contained the kernels that were ground using an endless press (IBG Monforts Oekotec $\mathrm{GmbH}$, Mönchengladbach, Germany). An aliquot of collected argan oil was immediately analyzed. Remaining oil was stored at $60{ }^{\circ} \mathrm{C}$ and analyses were repeated after every week (acidity, peroxide value, and $p$-anisidine index) or after $3,6,10$, and 12 weeks of storage (tocopherol, sterol, and fatty acid contents).

Cactus fruit was picked in Sidi Ifni in July, 2014. The fruit was manually peeled and cactus seeds were collected, air-dried and finally ground using the same type of endless press as that used for argan oil.

For the study, oil samples were stored in a Memmert UF110 plus oven (Memmert GmbH, Schwabach, Germany) equipped with a Kimo KTT310-RF thermostat at a constant temperature of $60 \pm 1{ }^{\circ} \mathrm{C}$.

\subsection{Chemical analyses}

An aliquot of each oil was analyzed immediately after oil extraction. The remaining oil was stored at $60{ }^{\circ} \mathrm{C}$ and an amount necessary for the analysis was subtracted every three weeks. Analyses were performed over a 12 week-period.

The chemical and physical parameters (acidity, peroxide index, $p$-anisidine value, and fatty acid content) were analyzed, in triplicate, following the analytical methods described in Regulations EC 2568/91 (Commission Regulation, 1991).

Fatty acid composition was determined as their corresponding methyl esters by gas chromatography on a CPWax 52CB column (30 m x $0.25 \mathrm{~mm}$ i.d., $0.25 \mu \mathrm{m}$ film thickness) using $\mathrm{He}$ (flow rate $1 \mathrm{~mL} / \mathrm{mn}$ ) as carrier gas. Oven, injector, and detector temperatures were set at 170, 200, and $230{ }^{\circ} \mathrm{C}$; respectively. Injected quantity was $1 \mu \mathrm{L}$ for each analysis (Gharby et al., 2011).

Sterol composition was determined after trimethylsilylation of the crude sterol fraction using a Varian 3800 instrument equipped with a VF-1 ms column ( $30 \mathrm{~m} \times 0.25 \mathrm{~mm}$ i.d., $0.25 \mu \mathrm{m}$ film thickness) and using Helium (flow rate $1.6 \mathrm{~mL} / \mathrm{min}$ ) as carrier gas. Column temperature was isothermal at $270{ }^{\circ} \mathrm{C}$, the injector and detector temperature was $300{ }^{\circ} \mathrm{C}$. Injected quantity was $1 \mu \mathrm{L}$ for each analysis (Gharby et al., 2011).

On the basis of the AOCS Official method Ce 8-89 (Gharby et al., 2011), tocopherol content was determined by HPLC using Shimadzu instruments equipped with a $\mathrm{C} 18$-Varian column $(25 \mathrm{~cm} \mathrm{x} 4 \mathrm{~mm})$. Detection was performed using a fluorescence detector (excitation wavelength $290 \mathrm{~nm}$, detection wavelength $330 \mathrm{~nm}$ ). The eluent used was a 99:1 isooctane/ isopropanol $(\mathrm{V} / \mathrm{V})$ mixture, at a flow rate of $1.2 \mathrm{~mL} / \mathrm{min}$.

\subsection{Statistical analyses}

Values reported are the mean values $\pm \mathrm{SE}$ of 3 replicates. The significance level was set at $\mathrm{P}=0.05$. Separation of mean values was performed by Tukey's test at the 0.05 significance level.

\section{RESULTS AND DISCUSSION}

The cosmetic properties of cactus and argan oils are mainly attributed to their high unsaturated fatty acid contents and to the concomittant presence of elevated levels of phytosterols and tocopherols (Ciriminna et al., 2017; Labuschagne and Hugo, 2010; Ramadan and Mörsel, 2003; Charrouf and Guillaume, 1999; Salvo et al., 2002). Therefore, we decided to examine the 
variations in the contents of these three types of constituents under accelerated aging conditions. Storage was prolonged for 12 weeks, and analyses of these two markers were performed every 3 weeks.

\subsection{Fatty acid content}

For both oils, initial fatty acid content was found in the range of published values for cactus seed oil from Morocco (Zine et al., 2013; Taoufik et al., 2015), or of geographically close origin (Monia et al., 2005). Accelerated aging did not induce any significant modification in the fatty acid content or distribution and, even after 12 weeks at $60{ }^{\circ} \mathrm{C}$, the linoleic acid content in cactus seed oil was found to be similar to that of the freshly prepared oil (Table 1 ).

\subsection{Sterol content}

Sterols were the second class of compounds investigated. Cactus seed and argan oils are both rich in phytosterols but they only share $\Delta^{7}$-avenasterol as common sterols. In addition to $\Delta^{7}$-avenasterol, the sterols in cactus seed oil are campesterol, $\quad$ stigmasterol, $\quad \beta$-sitosterol, $\Delta^{5}$-avenasterol, and $\Delta^{7}$-stigmasterol (El Mannoubi et al., 2009). In addition, argan oil sterols are schottenol, spinasterol, and stigmasta-8,22-diene (Charrouf and Guillaume, 1999). As observed for fatty acids, no significant variations in sterol content was observed for both oils during 12 weeks of accelerated aging (data not shown). In cactus seed oil, the content of $\beta$-sitosterol, as the main sterol, remained constant at over $78 \%$ and that of campesterol at around $10 \%$.

\subsection{Tocopherol content}

Tocopherols, whose anti-oxidant properties are presented as important for the oil's cosmetic properties, were also investigated (Guillaume and Charrouf, 2011). Whereas argan oil contains $\alpha$-, $\beta-, \gamma-$, and $\delta$-tocopherols ( $\beta$ - being minoritary) (Charrouf and Guillaume, 1999), cactus seed oil does not contain $\beta$-tocopherol (El Mannoubi et al., 2009). Therefore, only the changes in those three tocopherols that the two oils have in common were investigated over 12 weeks of accelerated aging conditions.

Tocopherol distribution in freshly prepared cactus seed oil is different from that of argan oil. In argan oil, $\alpha$ - and $\delta$-tocopherol are present in an amount which is 10 times greater than in cactus seed oil (Table 2). The $\gamma$-tocopherol content is similar in both oils (Table 2). The concentration in $\alpha$-tocopherol remained stable in cactus seed oil for 6 weeks, after which it began to significantly decrease, suggesting the occurrence of the oxidative processes. In argan oil, variations in $\alpha$-tocopherol were not significant over the 12 weeks. The content in $\gamma$-tocopherol in cactus seed oil turned out to be more stable over the study period and only began to significantly decrease after the ninth week. At week-12, the $\gamma$-tocopherol content in cactus seed oil that had constantly been similar or slightly higher than that of argan oil, became inferior to that of argan oil, likely indicating the intense destruction of $\gamma$-tocopherol by oxidizing species. Under the same aging conditions, the $\gamma$-tocopherol content in argan oil decreased sooner since a significant variation in $\gamma$-tocopherol content was observable after week 3. However, the loss in $\gamma$-tocopherol remained moderate throughout the whole study. Initially low $\delta$-tocopherol content remained stable in cactus seed oil over the twelve weeks of study; whereas it had started to significantly decrease in argan oil after week-6. The total amount of tocopherol in both oils became significantly different after 9 weeks of storage.

TABLE 1. Fatty acid (\%) composition of cactus and argan seed oils during 12 weeks of storage at $60^{\circ} \mathrm{C}$.

\begin{tabular}{ccccccccccc}
\hline Week & \multicolumn{2}{c}{ Palmitic acid } & \multicolumn{2}{c}{ Stearic acid } & \multicolumn{2}{c}{ Oleic acid } & \multicolumn{2}{c}{ Linoleic acid } & \multicolumn{2}{c}{ Linolenic acid } \\
\hline & Cactus & Argan & Cactus & Argan & Cactus & Argan & Cactus & Argan & Cactus & Argan \\
\hline Initial & $12.3 \pm 0.1$ & $13.1 \pm 0.1$ & $3.4 \pm 0.1$ & $5.4 \pm 0.1$ & $20.4 \pm 0.5$ & $48.2 \pm 0.7$ & $61.8 \pm 0.9$ & $32.5 \pm 0.7$ & $0.3 \pm 0.1$ & $0.2 \pm 0.1$ \\
3 & $11.9 \pm 0.3$ & $13.8 \pm 0.4$ & $3.4 \pm 0.2$ & $5.7 \pm 0.1$ & $21.5 \pm 0.5$ & $48.2 \pm 0.6$ & $61.8 \pm 0.4$ & $32.9 \pm 0.9$ & $0.3 \pm 0.1$ & $0.2 \pm 0.1$ \\
6 & $12.2 \pm 0.2$ & $13.9 \pm 0.7$ & $3.4 \pm 0.2$ & $5.6 \pm 0.5$ & $19.2 \pm 0.3$ & $47.9 \pm 0.6$ & $63.4 \pm 0.5$ & $32.9 \pm 0.5$ & $0.3 \pm 0.1$ & $0.2 \pm 0.1$ \\
9 & $12.2 \pm 0.2$ & $13.8 \pm 0.1$ & $3.4 \pm 0.1$ & $5.8 \pm 0.2$ & $20.4 \pm 0.2$ & $47.9 \pm 0.5$ & $61.8 \pm 0.2$ & $32.9 \pm 0.5$ & $0.3 \pm 0.1$ & $0.1 \pm 0.1$ \\
12 & $12.3 \pm 0.2$ & $13.9 \pm 0.2$ & $3.4 \pm 0.1$ & $5.6 \pm 0.2$ & $20.4 \pm 0.2$ & $48.1 \pm 0.4$ & $61.8 \pm 0.2$ & $32.9 \pm 0.3$ & $0.3 \pm 0.1$ & $0.1 \pm 0.1$ \\
\hline
\end{tabular}

Each values is the mean of 3 replicates, Separation of mean values was performed by Tukey's test at the 0.05 significance level 
TABLE 2. Tocopherol (mg/kg) composition of cactus and argan seed oils during 12 weeks of storage at $60{ }^{\circ} \mathrm{C}$.

\begin{tabular}{ccccccccc}
\hline Week & \multicolumn{2}{c}{$\boldsymbol{\alpha}$-tocopherol } & \multicolumn{2}{c}{$\gamma$-tocopherol } & \multicolumn{2}{c}{$\boldsymbol{\delta}$-tocopherol } & \multicolumn{2}{c}{ Total } \\
\hline & Cactus & Argan & Cactus & Argan & Cactus & Argan & Cactus & Argan \\
\hline Initial & $8.4 \pm 0.2^{\mathrm{a}}$ & $72 \pm 2^{\mathrm{a}}$ & $595 \pm 10^{\mathrm{a}}$ & $585 \pm 9^{\mathrm{a}}$ & $5.7 \pm 0.1^{\mathrm{a}}$ & $82 \pm 2^{\mathrm{a}}$ & $622 \pm 5^{\mathrm{a}}$ & $766 \pm 6^{\mathrm{a}}$ \\
3 & $8.2 \pm 0.2^{\mathrm{a}}$ & $70 \pm 1^{\mathrm{a}}$ & $593 \pm 14^{\mathrm{a}}$ & $5812 \pm 11^{\mathrm{a}}$ & $5.7 \pm 0.1^{\mathrm{a}}$ & $81 \pm 2^{\mathrm{a}}$ & $618 \pm 8^{\mathrm{a}}$ & $762 \pm 10^{\mathrm{a}}$ \\
6 & $8.2 \pm 0.1^{\mathrm{a}}$ & $70 \pm 1^{\mathrm{a}}$ & $581.2 \pm 8.5^{\mathrm{a}}$ & $547 \pm 5^{\mathrm{b}}$ & $5.5 \pm 0.1^{\mathrm{a}}$ & $77 \pm 3^{\mathrm{a}}$ & $604 \pm 7^{\mathrm{a}}$ & $703 \pm 10^{\mathrm{a}}$ \\
9 & $7.6 \pm 0.2^{\mathrm{b}}$ & $68 \pm 1^{\mathrm{a}}$ & $573 \pm 5^{\mathrm{a}}$ & $549 \pm 11^{\mathrm{b}}$ & $5.7 \pm 0.2^{\mathrm{a}}$ & $62 \pm 1^{\mathrm{b}}$ & $598 \pm 8^{\mathrm{a}}$ & $692 \pm 7^{\mathrm{a}}$ \\
12 & $6.6 \pm 0.1^{\mathrm{c}}$ & $65 \pm 2^{\mathrm{a}}$ & $514 \pm 11^{\mathrm{b}}$ & $533 \pm 10^{\mathrm{b}}$ & $5.2 \pm 0.1^{\mathrm{a}}$ & $39 \pm 1^{\mathrm{c}}$ & $536 \pm 5^{\mathrm{b}}$ & $649 \pm 6^{\mathrm{b}}$ \\
\hline
\end{tabular}

Each values is the mean of 3 replicates, Separation of mean values was performed by Tukey's test at the 0.05 significance level

a,b,c: Values indexed with the different letters within the same column are significantly different.

These differences in tocopherol content variations between the two oils clearly point out that anti-oxidative processes occurring during aging in cactus seed and argan oils are either different or that responses to oxidative processes are different. The differences may reflect the formation of different oxidizing species resulting mainly from oleic (argan oil) or linoleic (cactus oil) acids. They may also reflect a different oxidative behavior of synergestic associations of the fatty acids with other anti-oxidant molecules, possibly the sterols and/or phospholipids (Gharby et al., 2012b; Zaanoun et al., 2014). Despite the observed different reactivity of cactus seed and argan oil tocopherols in accelerated oxidative conditions, it is noteworthy that the initial cactus oil total tocopherol content was $81 \%$ of that of argan oil. After 12 weeks of accelerated aging, and different oxidative processes, the total tocopherol content in cactus seed oil was still $81 \%$ of that of argan oil, but on a lower total level.

\subsection{Acidity, peroxide, and $p$-anisidine values}

Once a variation in the content of the antioxidant tocopherols was identified, it was decided to further evaluate the shelf-life of argan and cactus seed oils from Morocco, by examining the variations in two other key oxidation markers likely to be modified during prolonged storage at $60{ }^{\circ} \mathrm{C}$. Hence, the peroxide and $p$-anisidine values were determined. The variations in oil acidity, a parameter important for cosmetics, were also examined.

The composition of cactus seed oil depends on its geographical origin (Ciriminna et al., 2017), as does its acidity for which large variations have also been reported. Acidity values as low as $0.56 \%$ for oleic acid (Zine et al., 2013) and as high as $5.08 \%$ for oleic acid (De Wit et al., 2016) have been reported for cactus oils of various geographical origins. We found an acidity of $1.15 \%$ for oleic acid in our cactus seed oil sample (Figure 1). Such acidity, which is twice that found in a previous study on a different batch of Moroccan cactus seed oil (Zine et al., 2013), clearly indicates that the geographical origin is neither the only factor influencing cactus seed oil acidity nor the most influential factor. The maturity of the fruit and/or the seed water-content, two conditions that inevitably superimpose, are two parameters that also likely dramatically influence the acidity of cactus oil. If this later parameter has already been suggested (De Wit et al., 2016) and could be evaluated by a moisture measurement, the huge number of seeds in a cactus fruit and their different degrees of maturity, unfortunately makes a global evaluation of cactus seeds difficult. The presence of enzymes or of unidentified residues formed after oil extraction has also been suggested to explain the high acidity of cactus seed oil (De Wit et al., 2016).

After storage at $60{ }^{\circ} \mathrm{C}$, the calculated acidity of the cactus oil sample increased almost linearly until week 9 to reach $2.87 \%$ for oleic acid (Figure 1). The slope of the straight line, which describes hydrolysis, followed a kinetic second order. Such a value corresponds to a hydrolysis rate estimated to be $2 \times 10^{-3} \mathrm{mmol}$ of triglyceride/ week. The initial acidity value in argan oil was $0.3 \%$ for oleic acid, which is very low, far lower than cactus oil. The trend of hydrolysis followed a linear process, such as the cactus oil, during storage at $60{ }^{\circ} \mathrm{C}$ for the 12 weeks of our study but its slope was twice as low as that of cactus seed oil (Figure 1). Accordingly, the hydrolysis of argan oil during the storage period occurred at a rate estimated to be $0.75 \times 10^{-3} \mathrm{mmol}$ of triglyceride/week, a rate almost thrice lower than that of cactus oil. Hence, cactus seed oil appears 
to be much more sensitive to hydrolysis than argan oil.

Accelerated aging is a good measure to evaluate lipid peroxidation (Stewart and Bewley, 1980). Therefore, we evaluated the oxidation degree of cactus seed oil by examining its peroxide value (Figure 2). Cactus seed oil had an initial peroxide value of $4.59 \mathrm{meq} \mathrm{O}_{2} / \mathrm{kg}$. If much lower peroxide values have been previously reported (Matthäus and Özcan, 2011; Özcan and Al Juhaimi, 2011) for cactus seed oil, this value is similar to that already reported for Moroccan cactus oil (Zine et al., 2013) and much lower than that determined for South African cactus oil for which a peroxide value as high as $33.6 \mathrm{meq} \mathrm{O}_{2} / \mathrm{kg}$ has been observed (De Wit et al., 2016). The first weeks of storage of cactus seed oil at $60{ }^{\circ} \mathrm{C}$ could be identified as the oxidative propagation phase and the cactus oil peroxide value for cactus seed oil reached a maximum value of $9.43 \mathrm{meq} \mathrm{O}_{2} / \mathrm{kg}$ at week 3. After that, some peroxides began to be broken into secondary oxidation products as attested by the decrease for 2 weeks (from week 3 to week 5) in the peroxide value. After 6 weeks of storage, the kinetics of the peroxidation became faster than that of the secondary oxidation formation and large amounts of peroxides were again detected. After 12 weeks, the peroxide value reached a maximum value of $39.41 \mathrm{meq}$ $\mathrm{O}_{2} / \mathrm{kg}$. At that moment, the $\gamma$-tocopherol content underwent a large decrease, likely attesting to its destruction by the massive formation of peroxides. Interestingly, we observed that the $\alpha$-tocopherol content in cactus oil decreased after 6 weeks. This also suggests an active and early involvement of $\alpha$-tocopherol in the prevention of peroxide formation. Tocopherol intervention could be sequential, $\alpha$-tocopherol would participate in cactus seed oil preservation in a first step and $\gamma$-tocopherol in a second phase.

In argan oil, the propagation phase lasted 6 weeks (twice as long as that of cactus seed oil) and additional peroxides began to significantly appear after 10 weeks. After 12 weeks, the peroxide value of argan oil reached $33.6 \mathrm{meq}$ $\mathrm{O}_{2} / \mathrm{kg}$, a value almost $15 \%$ lower than that of cactus seed oil. Consequently, peroxide formation is much faster in cactus oil than in argan oil.

To get a better picture of the secondary oxidation product formation, the $p$-anisidine value for our oils as a function of the time of storage were determined. For cactus oil, a strong increase in the $p$-anisidine value was observed after 2 weeks confirming the decrease in peroxide value observed after 3 weeks. The $p$-anisidine value continued to increase regularly, attesting to the constant formation of secondary oxidation products during storage at $60{ }^{\circ} \mathrm{C}$. In argan oil, secondary oxidation products were formed after 7 weeks of storage, again confirming the plateau observed in peroxide formation after 8 weeks.

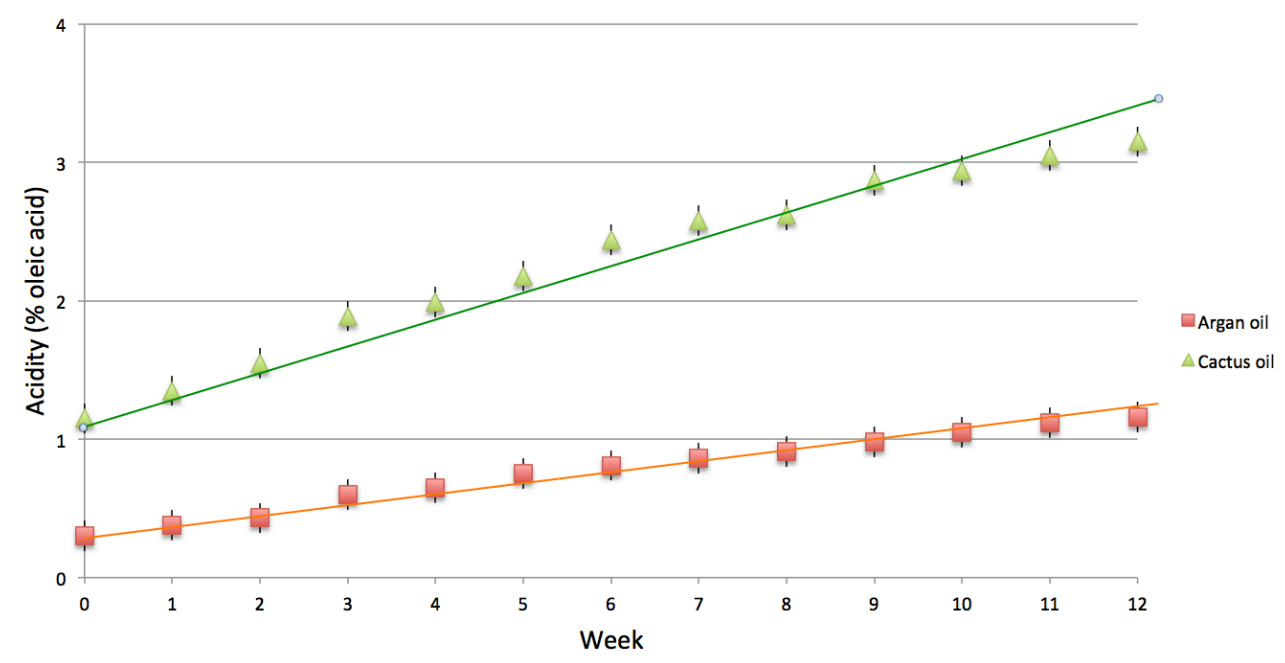

FIGURE 1. Evolution of acidity (in g/100 of oil) in cactus and argan seed oils upon 12 weeks of storage at $60{ }^{\circ} \mathrm{C}$. Values represent the mean of 3 replicates and error bars represent standard variations. 


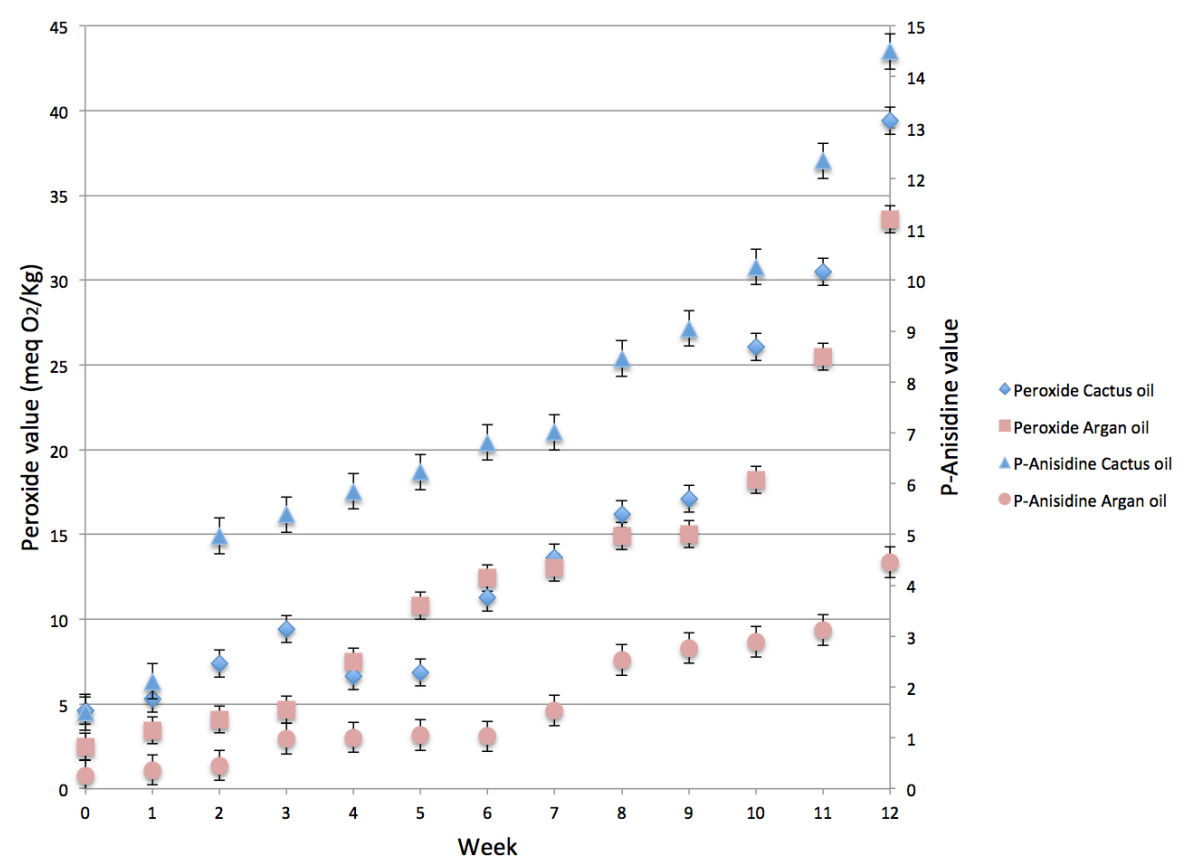

FIGURE 2. Evolution of peroxide value (meq $\mathrm{O}_{2} / \mathrm{kg}$ of oil) and $p$-anisidine index of cactus and argan seed oils upon 12 weeks of storage at $60{ }^{\circ} \mathrm{C}$. Values represent the mean of 3 replicates and error bars represent standard variations.

\section{CONCLUSION}

It should be kept in mind that cactus seed oil is not a product as homogenous as argan oil can be, and its content in fatty acids as well as minor components can undergo large variations, as do its physico-chemical parameters. Consequently, the oil from cactus seeds is susceptible to various oxidative processes and to exhibit high instability, which makes it inadequate for industrial use.

Although we studied cactus seed and argan oils originating from the same geographical area, the oxidative sensitivity of cactus seed oil was fond to be much higher than that argan oil. This difference likely comes from the high content in linoleic acid in cactus seed oil and possibly also from improper technological processes used for cactus seed oil extraction and/or insufficient care in its handling during extraction or storage.

When satisfactorily protected from sunlight and at room temperature, cosmetic argan oil has a shelf-life of one year (Gharby et al., 2014), cactus seed oil's shelf-life can be estimated to be only between 3 and 6 months. Therefore, special care, such as refrigeration or storage under an inert atmosphere, should be seriously considered for cactus seed oil prolonged storage. If adequate precautions are taken, cactus seed oil deserves to find its place in the cosmetics market. Therefore, prickly pear fruit, often not appreciated and even disregarded (Piga, 2004), due to the high number and size of its seeds, may now become highly revalued given its new added value.

\section{ACKNOWLEDGMENTS}

We thank the Association Ibn Al Baytar for its interest in this work and financial support. This work was carried out in the frame of the PMARS2015-104.

\section{REFERENCES}

AOCS Official Method Ce 8e89. 1983. In American Oil Chemist's Society, Determination of tocopherols and tocotrienols in vegetable oils and fats by HPLC. Uniform Methods Committee. Champaign, Il, AOCS.

Charrouf Z, Guillaume D. 1999. Ethnoeconomical, ethnomedical, and phytochemical study of Argania spinosa (L.) Skeels. J. Ethnopharmacol. 67, 7-14. https:// doi.org/10.1016/S0378-8741(98)00228-1

Charrouf Z, Guillaume D. 2008. Argan oil: Occurrence, composition and impact on human health. Eur. J. Lipid Sci. Technol. 110, 632-636. https://doi.org/10.1002/ejlt.200700220 
Charrouf Z, Guillaume D. 2014. Argan oil, the 35-years-of-research product. Eur. J. Lipid Sci. Technol. 116, 1316-1321. https://doi.org/ 10.1002/ejlt.201400261

Charrouf Z, Guillaume D, Driouich A. 2002. The argan tree, an asset for Morocco. Biofutur. 220, 54-56.

Charrouf Z, Guillaume D. 2018. The argan oil project: going from utopia to reality in 20 years. Oilseeds \& Fats, Crops and Lipids 25, D209. https://doi.org/10.1051/ocl/2018006

Ciriminna R, Bongiorno D, Scurria A, Danzì C, Timpanaro G, Delisi R, Avellone G, Pagliaro M. 2017. Sicilian Opuntia ficus-indica seed oil: Fatty acid composition and bio-economical aspects. Eur. J. Lipid. Sci. Technol. 119 (11), 1700232. https://doi.org/10.1002/ejlt.2017002 32

Commission Regulation (EEC) (2568/91) 1991. Official Journal of the European Community, L 248, 1.

Coskuner Y, Tekin A. 2003. Monitoring of seed composition of prickly pear (Opuntia ficus indica L.) fruits during maturation period. $J$. Sci. Food Agric. 83, 846-849. https://doi.org/ 10.1002/jsfa.1423

El Finti A, El Boullani R, Fallah M, Msanda F, El Mousadik A. 2013. Assessment of some agrotechnological parameters of cactus pear fruit (Opuntia ficus-indica Mill.) in Morocco cultivars. J. Med. Plants Res. 7, 2574-2583

El Mannoubi I, Barrek S, Skanji T, Casabianca H, Zarrouk H. 2009. Characterization of Opuntia ficus-indica seed oil from Tunisia. Chem. Nat. Comp. 45, 616-620. https://doi.org/10.1007/ s10600-009-9448-1

Feugang JM, Konarski P, Zou D, Stintzing FC, Zou C. 2006. Nutritional and medicinal use of Cactus pear (Opuntia spp.) cladodes and fruits. Front Biosci. 11, 2574-2589.

Gharby S, Harhar H, El Monfalouti H, Kartah B, Maata N, Guillaume D, Charrouf Z. 2012a. Chemical and oxidative properties of olive and argan oils sold on the Moroccan market. A comparative study. Med. J. Nutr. Metab. 5, 31-38. https://doi.org/10.1007/s12349-011-00 76-5

Gharby S, Harhar H, Guillaume D, Haddad A, Matthäus B, Charrouf Z. 2011. Oxidative stability of edible argan oil: A two-year study. LWT-Food Sci. Technol. 44, 1-8. https:// doi.org/10. 1016/j.lwt.2010.07.003

Gharby S, Harhar H, Guillaume D, Haddad A, Charrouf Z. 2012b. The origin of virgin argan oil's high oxidative stability unraveled. Nat. Prod. Commun. 7, 621-624. https://doi.org/ 10.1177/1934578X1200700520

Gharby S, Harhar H, Kartah B, Guillaume D, Chafchaouni I, Charrouf Z. 2014. Oxidative stability of cosmetic argan oil: a one-year study. J. Cosmetic Sci. 65, 81-87

Guillaume D, Charrouf Z. 2011. Argan oil and other argan products: Use in dermocosmetology. Eur. J. Lipid Sci. Technol. 113, 403-408. https://doi.org/10.1002/ejlt.2010 00417

Guillaume D, Charrouf Z. 2013. Argan oil for nutritional and skin care applications. $H P C$ Today 8, 28-30.

Guillaume D, Gharby S, Harhar H, Baba M. 2015. Opuntia ficus-indica and Balanites aegytiaca oils: two seed oils to watch. HPC Today 10, 45-48.

Harhar H, Gharby S, Guillaume D, Charrouf Z. 2010. Effect of argan kernel storage conditions on argan oil quality. Eur. J. Lipid Sci. Technol. 112, 915-920. https://doi.org/10.1002/ejlt.2009 00269

Labuschagne MT, Hugo A. 2010. Oil content and fatty acid composition of cactus pear seed compared with cotton and grape seed. J. Food Biochem. 34, 93-100. https://doi.org/10.1111/ j.1745-4514.2009.00266.x

Matthäus B, Guillaume D, Gharby S, Haddad A, Harhar H, Charrouf Z. 2010. Effect of processing on the quality of edible argan oil. Food Chem. 120, 426-432. https://doi.org/ 10.1016/j.foodchem.2009.10.023

Matthäus B, Özcan MM. 2011. Habitat effects on yield, fatty acid composition and tocopherol contents of prickly pear (Opuntia ficus-indica L.) seed oils. Scientia Hort. 131, 95-98. https:// doi.org/10.1016/j.scienta.2011.09.027

Monia E, Bourret E, Mondolot L, Attia H. 2005. Fatty acid composition and rheological behaviour of prickly pear seed oils. Food Chem. 93, 431-437. https://doi.org/10.1016/ j.foodchem.2004.10.020

Özcan MM, Al Juhaimi FY. 2011. Nutritive value and chemical composition of prickly pear seeds (Opuntia ficus-indica L.) growing in Turkey. Internat. J. Food Sci. Nutr. 62, 533-536. https://doi.org/10.3109/09637486.20 11.552569

Piga A, 2004. Cactus pear: a fruit of nutraceutical and functional importance. J. Prof. Assoc. Cactus Dev. 6, 9-22. 
Ramadan MF, Mörsel JT. 2003. Oil cactus pear (Opuntia ficus-indica L.). Food Chem. 82, 339-345. https://doi.org/10.1016/S0308-8146 (02)00550-2

Salvo F, Galati EM, Lo Curto S, Tripodo MM. 2002. Study on the chemical characterization of lipid composition of Opuntia ficus-indica L. seed oil. Riv. Ital. Sost. Grasse 79, 395-398.

Sawaya WN, Khan P. 1982. Chemical characterization of prickly pear seed oil, Opuntia ficus-indica. J. Food Sci. 47, 2060-2061. https://doi.org/10.1111/j.1365-26 21.1982.tb12946.x

Stewart RRC, Bewley JD. 1980. Lipid peroxidation associated with accelerated Aging of soybean axes. Plant Physiol. 65, 245-248.

Taoufik F, Zine S, El Hadek M, Idrissi Hassani LM, Gharby S, Harhar H, Matthäus B. 2015. Oil content and main constituents of cactus seed oils Opuntia Ficus-indica of different origin in Morocco. Med. J. Nutr. Metab. 8, 85-92. https://doi.org/10.3233/MNM-150036
Waal HO de, Louhaichi M, Taguchi M, Fouché HJ, De Wit M. 2015. Development of a cactus pear agro-industry for the sub-Sahara Africa Region. Proceedings of International Workshop, University of the Free State, Bloemfontein, South Africa, $96 \mathrm{pp}$.

Wit M de, Hugo A, Shongwe N. 2016. Quality assessment of seed oil from selected cactus pear cultivars (Opuntia ficus-indica and Opuntia robusta). J. Food Process. Preserv. 41, e12898. https://doi.org/10.1111/jfpp.12898

Zaanoun I, Gharby S, Bakass I, Ait addi E, Ait ichou I. 2014. Kinetic parameter determination of roasted and unroasted argan oil oxidation under Rancimat test conditions. Grasas Aceites 65 (3), e033. https://doi.org/10.3989/gya.122 713

Zine S, Gharby S, El Hadek M. 2013. Physicochemical characterization of Opuntia ficus-indica Seed Oil from Morocco. Biosci. Biotech. Res. Asia, 10, 99-105. 